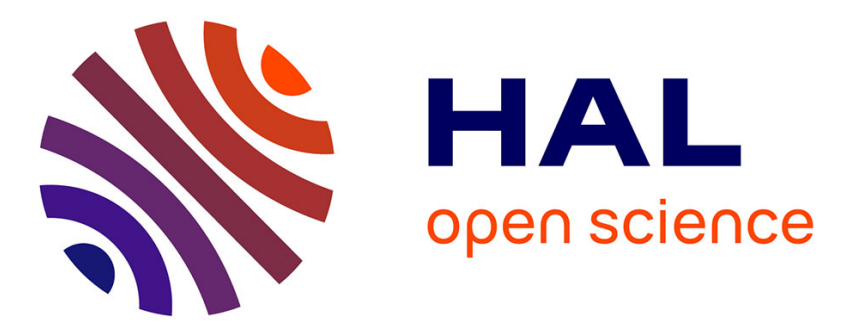

\title{
Femtosecond laser cutting of glass by controlled fracture propagation
}

\author{
K Mishchik, C Javaux, O Dematteo-Caulier, Stefan Skupin, B Chimier, G \\ Duchateau, A Bourgeade, R Kling, A Letan, C Hönninger, et al.
}

\section{- To cite this version:}

K Mishchik, C Javaux, O Dematteo-Caulier, Stefan Skupin, B Chimier, et al.. Femtosecond laser cutting of glass by controlled fracture propagation. Conference on Lasers and Electro-Optics, May 2015, San Jose, United States. 10.1364/CLEO_AT.2015.AM1K.3 . hal-01182090

\section{HAL Id: hal-01182090 \\ https://hal.science/hal-01182090}

Submitted on 30 Jul 2015

HAL is a multi-disciplinary open access archive for the deposit and dissemination of scientific research documents, whether they are published or not. The documents may come from teaching and research institutions in France or abroad, or from public or private research centers.
L'archive ouverte pluridisciplinaire HAL, est destinée au dépôt et à la diffusion de documents scientifiques de niveau recherche, publiés ou non, émanant des établissements d'enseignement et de recherche français ou étrangers, des laboratoires publics ou privés. 


\title{
Femtosecond laser cutting of glass by controlled fracture propagation
}

\author{
K. Mishchik ${ }^{1}$, C. Javaux ${ }^{2}$, O. Dematteo-Caulier ${ }^{1}$, S. Skupin ${ }^{1}$, B. Chimier 1 , G. Duchateau ${ }^{1}$, A. Bourgeade ${ }^{3}$, \\ R. Kling ${ }^{2}$, A. Letan ${ }^{4}$, C. Hönninger ${ }^{4}$, E. Mottay ${ }^{4}$, J. Lopez ${ }^{1}$ \\ ${ }^{1}$ UNIV BORDEAUX CNRS CEA, CELIA UMR5107, 33405 Talence, France. \\ ${ }^{2}$ ALPhANOV, Rue Francois Mitterand, 33400 Talence, France. \\ ${ }^{3}$ CEA/CESTA, 15 Avenue des Sablières, 33114 Le Barp, France. \\ ${ }^{4}$ AMPLITUDE SYSTEMES, 11, avenue de Canteranne, Cité de la Photonique, 33600 Pessac, France.
}

Author e-mail address: choenninger@amplitude-systemes.com

\begin{abstract}
We present the use of a compact femtosecond laser with 300-fs pulse duration and pulse energy on the order of $10 \mathrm{~s}$ of $\mu \mathrm{J}$ for the cutting of glass by controlled fracture propagation. OCIS codes: (000.0000) General; (000.0000) General [8-pt. type. For codes, see www.opticsinfobase.org/submit/ocis.]
\end{abstract}

Laser induced controlled fracture propagation [1] has great potential in cutting brittle materials such as glass or sapphire. This method is based on the ability to produce a mechanical stress by the absorption of the laser radiation in the volume of the material. Under specific conditions thermal stresses cause initiation of a top-down through crack which propagates along the laser beam trajectory. The cut parts are released without any mechanical assistance. The cutting sidewalls are smooth and free from any surface defects and debris. However, using $\mathrm{CO} 2$ or YAG lasers, this method has several drawbacks such as poor precision, uncontrolled cutting deviation or low effective cutting speed (few tens of $\mathrm{mm} / \mathrm{s}$ ). There exist techniques to improve cutting quality or proceeding speed [2], however, they could not overcome all the shortcomings of the convenient method at the same time and added extra-cost and complexity to the process. Thus, there is the need to find solutions how to make this technology fast, precise and versatile for different materials.

In this paper we demonstrate that the use of ultrashort pulse laser sources may be advantageous since it allows to overcome several restrictions of the convenient method. We report on the laser cutting of thick soda-lime glass samples using an Yb-doped fiber femtosecond laser (Satsuma, Amplitude Systems, 5W, 1030nm, 300fs). Cutting was achieved at high repetition rate $(500 \mathrm{kHz})$ by focusing the laser beam with a low numerical aperture (NA 0.05) inside the glass sample, which can be translated in three dimensions (Fig. 1a). We have investigated the effect of the experimental parameters, such as numerical aperture, pulse energy, single pulse or burst-mode, and repetition rate on the laser affected zone (LAZ). We demonstrate that in a specific regime an elongated LAZ depicted in Fig. 1b can produce single-pass full cutting of $1 \mathrm{~mm}$-thick glass by controlled fracture propagation. The crack follows straight and curve trajectories with a radius down to $1 \mathrm{~cm}$ with a federate of $1 \mathrm{~mm} / \mathrm{s}$. Cutting edge and rim have been characterized using confocal optical and scanning electron microscopies (Fig. 4c-d). We have measured a roughness of the edge to be below $100 \mathrm{~nm}$ and a path deviation below $10 \mu \mathrm{m}$ compared to a flat surface, which we attribute to variation of the LAZ diameter along the sample depth.

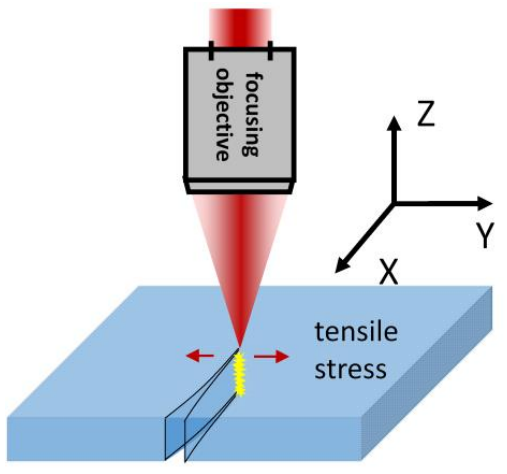

a)

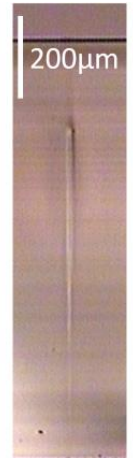

b)

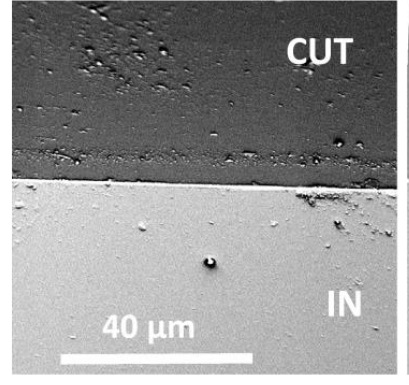

c)

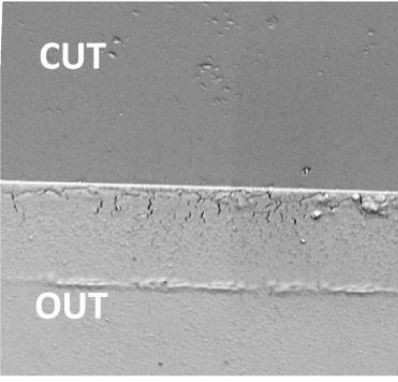

d)

Fig.1. a) Experimental setup. b) Microscopy image of the elongated and narrow LAZ reaching its length of about $800 \times 20 \mu \mathrm{m}$. SEM images showing cutting sidewall and rim qualities on front (c) and rear surfaces (d). There is no visible chipping. 
We also performed theoretical simulations of thermal effects during laser irradiation. The numerical model is based on nonlinear light absorption in the presence of intense optical fields, nonlinear propagation defined by the Kerreffect, and takes into account influence of free carriers on laser absorption and propagation. Modeling shows that at loose focusing conditions the laser energy is absorbed in a narrow and rather long zone, i.e., a filament is formed. At high repetition rate, the absorbed energy does not dissipate before the subsequent pulse arrives, which results in a local raise of the temperature and generation of high tensile stress in the vicinity of the LAZ. Eventually thermal stress initiates the crack formation along the whole glass depth. The intrinsic property of nonlinear absorption makes this cutting method suitable for wide range of glasses and transparent ceramics, without any need of prior treatment of the samples.

1) R. M. Lumley, Controlled separation of brittle materials using a laser, Am. Ceram. Soc. Bull. 48, 850-854 (1968).

2) S. Nisar, L. Li, \& M. A. Sheikh, Laser glass cutting techniques-A review. Journal of Laser Applications, 25 (2013) 